\title{
Chemical Treatment for Removal of Heavy Metals from Industrial Wastewater
}

\author{
H. I. Abdel-Shafy \\ Water Research \& Pollution Control Department, National \\ Research Centre, Dokki (Affiliation ID: 60014618), Cairo, Egypt.
}

\begin{abstract}
THE OBJECTIVE of the present study is treatment of industrial wastewater that is artificially contaminated with a combination of soluble salts of $\mathrm{Ni}, \mathrm{Cu}$ and $\mathrm{Mn}$ in the concentration of $10 \mathrm{mg} / \mathrm{l}$ each. The treatment is focused on employing chemical coagulants and coagulant aids for the removal and co-precipitation of heavy metals. Variable doses of the chemical coagulants at different $\mathrm{pH}$ were examined. The physical and chemical characteristics and the level of $\mathrm{Cu}, \mathrm{Ni}$ and $\mathrm{Mn}$ in the industrial wastewater are given. When Sodium hydroxide was employed at $\mathrm{pH}$ 9.5, removal rate reached 97.5, 96.0 and $90.0 \%$ for $\mathrm{Cu}, \mathrm{Ni}$ and $\mathrm{Mn}$, respectively. On the other hand, the use of $50 \mathrm{mg} / \mathrm{l}$ ferric chloride in combination with sodium hydroxide at different $\mathrm{pH}$ was studied. At $\mathrm{pH} 12.0$, all the studied metals were removed at the rate of $98 \%$. When $70 \mathrm{mg} / \mathrm{l}$ alum was employed in combination with $\mathrm{NaOH}$ at different $\mathrm{pH}$, results indicated that $100 \%$ of $\mathrm{Cu}, 100 \%$ of $\mathrm{Ni}$ and $84 \%$ of $\mathrm{Mn}$ were removed at $\mathrm{pH} 12.0$. Further study was carried out using lime at different doses. At $\mathrm{pH} 11.0$, the removal rate reached over $100 \%$ for $\mathrm{Cu}$ and $\mathrm{Ni}$ each and $93 \%$ for $\mathrm{Mn}$. Limestone $\left(\mathrm{CaCO}_{3}\right)$ at different doses was investigated. Using $1.0 \mathrm{~g} / 1$ limestone raised the $\mathrm{pH}$ from 2.0 to 5.85 and the removal of $\mathrm{Cu}, \mathrm{Ni}$ and $\mathrm{Mn}$ reached 100, 90.2 and $75.1 \%$ respectively. By increasing the $\mathrm{CaCO}_{3}$ dose to $3.0 \mathrm{~g} / \mathrm{l}$, more than $100 \%$ of $\mathrm{Cu}$ and $\mathrm{Ni}$ each was achieved while $\mathrm{Mn}$ was removed at $90.6 \%$. It was noticed that increasing the limestone dose up to $5.0 \mathrm{~g} / \mathrm{l}$ did not increase the $\mathrm{pH}$ more than 8.0. This can be attributed mainly to the buffering system of limestone. It was concluded that the precipitation of metals is governed by the solubility product. Since all effluent guidelines require an effluent $\mathrm{pH}$ between 6 and 9, the use of carbonate treatment is, therefore, recommended because of its buffering capacity value which is around $\mathrm{pH}$ 7. Still $\mathrm{CaO}$ provides substantial precipitation efficiency and an economic mean of treatment. The disadvantage is the difficulty to control the $\mathrm{pH}$ of the liquid waste. However, this problem could be overcome by using acid to control the $\mathrm{pH}$ if needed.
\end{abstract}

Keywords: Heavy metals, Removal, Chemical coagulation, Industrial wastewater, Precipitation and co-precipitation, Copper, Nickel and Manganese.

Heavy metals are among the most hazard pollutants that affect both the environment and man health as well. Several sources of heavy metals in the environment are anthropogenic in nature ${ }^{(1)}$. Besides, heavy metals content in 
non-polluted soil is largely depending on the rocks from which the soil parent materials were driven. Meanwhile, the weathering process is quite relevant ${ }^{(2)}$. In this respect, heavy metals can have a detrimental effect on organisms in the environment as well as on humans who ingest them.

The presence of metals in trace amounts in the environment is fundamental. Some metals such as Fe, Mn and $\mathrm{Zn}$ are considered essential elements for plant growth and thus play an important role in the biochemical cycle ${ }^{(3)}$. On the other hand, some metals such as $\mathrm{Hg}, \mathrm{As}, \mathrm{Cd}$ and $\mathrm{Pb}$ are considered very toxic to plant ${ }^{(3)}$. For instantce, early anti-fouling paints used mercury as a base. It was not until the public health tragedy of mercury contamination of Minimata Bay, Japan, in the 1950's that anybody even became aware of the problems caused by heavy metals in the aquatic environment ${ }^{(4)}$. It was at this point that there was a switch from mercury to tributyl-tin (TBT) as the base for anti-fouling paint. However, switching to TBT did not resolve all of the problems having to do with heavy metals in bottom paint ${ }^{(5)}$.

Man has set up complex treatment processes to prevent or control pollution from wastewater reaching the environment. The principle objective in wastewater treatment is to eliminate or reduce contaminants to levels that cause no adverse effects on humans or the receiving environment ${ }^{(6,7)}$. A common method of removing heavy metals from wastewater has been to mix it with sewage, where conventional primary, secondary and tertiary treatment would then remove heavy metals. However, secondary and tertiary processes require high input of technology, energy and chemicals ${ }^{(8,9)}$. The costs, maintenance and operation of such technology are of great concern ${ }^{(7,10)}$. Such treatment processes should, therefore, be very attractive and economically justifiable for large-scale treatment plants, especially in cash-strapped third world countries. A cheaper, but efficient treatment technology was therefore sought such as oxidation ponds, constructed wetlands and trickling filter ${ }^{(11,12)}$.

It is worth mentioning that heavy metals are ubiquitous in natural waters at low concentrations ranged between ppb and $\mathrm{ppm}{ }^{(13)}$. Due to their refractory nature, their bioaccumulation in the food chain and potential toxicity, heavy metals may have an adverse impact on the environment ${ }^{(4)}$. As result a great concern has been arising in the last few decades stressing the need for effective wastewater treatment methods for metals removal ${ }^{(1,14,15)}$.

Metals exist in wastewater in many forms, including soluble, insoluble, inorganic, metal organic, reduced, oxidized, free metal, precipitated, adsorbed and in complex formation ${ }^{(1)}$. Treatment processes for metals removal must be selected according to the existing form of the metal. Otherwise, the metal must be converted to a suitable form compatible with the removal process ${ }^{(16,17)}$. In general, to be removed from wastewater, metals must be precipitated or otherwise attached to an insoluble form through adsorption or ion-exchange ${ }^{(17)}$. A number of soluble metal ions are simply precipitated on addition to

Egypt. J. Chem. 58, No. 1 (2015) 
wastewater ${ }^{(6)}$. But this natural removal mechanism is most effective at high metal concentrations and is usually not sufficient to reduce metals to the levels required by water quality standards or safe reuse ${ }^{(7,18)}$.

The objective of the present investigation is to study the effect of different precipitants and chemical coagulants on the removal of $\mathrm{Ni}, \mathrm{Cu}$ and $\mathrm{Mn}$ from the industrial wastewater. Therefore, it is found essential to select the food industrial wastewater because it contains high level of suspended solids of plant origin as organic bio-waste. Level of heavy metals in this wastewater was also determined. Evaluation and correlation between different chemical coagulants for metals removal are also the aim of this work.

\section{Material and Methods}

The industrial wastewater of a selected food company was used in this study. Reagent grade soluble salts of $\mathrm{Ni}\left(\mathrm{SO}_{4}\right) \cdot 6 \mathrm{H}_{2} \mathrm{O}, \mathrm{Cu}\left(\mathrm{SO}_{4}\right) \cdot 5 \mathrm{H}_{2} \mathrm{O}$ and $\mathrm{Mn}\left(\mathrm{SO}_{4}\right) \cdot \mathrm{H}_{2} \mathrm{O}$ were added to this wastewater to provide $10 \mathrm{mg} / \mathrm{l}$ of each metal as an artificial contaminated industrial liquid waste. Reagent grade concentrated $\mathrm{H}_{2} \mathrm{SO}_{4}$ was used to decrease the $\mathrm{pH}$ of the wastewater to range of 2.0 through the entire study. The investigated precipitants, coagulants and coagulant aids are: sodium hydroxide, $\mathrm{FeCl}_{3}$, alum, lime $(\mathrm{CaO})$ and limestone $\left(\mathrm{CaCO}_{3}\right)$. All the chemical coagulant solutions were freshly prepared prior experimentation.

The "Jar Test" procedure, as devised and modified by Culp and Culp ${ }^{(19)}$ was used in all experiments. One of these "Jars" was kept as the "control one" without adding any chemical treatment. The precipitants were added during the flash mixing process at the speed of $400 \mathrm{rpm}$ for a period of $1 \mathrm{~min}$ followed by flocculation at the speed of $40 \mathrm{rpm}$ for a period of $20 \mathrm{~min}$. The mixtures were left $30 \mathrm{~min}$ for settling ${ }^{(19)}$. The residual metals were determined in the supernatant of each jar.

The concentration of nickel, copper and manganese was determined in the acidified samples. The acidification was carried out by concentrated nitric acid to $\mathrm{pH}$ below $2.0^{(16)}$. For determination of heavy metals atomic absorption spectrophotometer "Instrumental Laboratories" model (551) equipped with heated Graphite Atomizer Model (651) and deuterium background corrector was used for this purpose.

Meanwhile, the physical and chemical characteristics of the food industrial wastewater was determined monthly over a period of twelve months. All analytical procedures were carried out according to the Standard Methods (APHA) ${ }^{(20)}$.

\section{Results and Discussion}

The physical and chemical characteristics of the industrial wastewater are given in Table 1. The $\mathrm{pH}$ of this wastewater ranged from slight alkaline to neutral and it was highly turbid at an average of 1040 NTU. The total solids were high and the total suspended solids were moderate at the average of 1632 and $485 \mathrm{mg} / \mathrm{l}$, respectively. 
The electric conductivity ranged from 600 to $1000 \mu \mathrm{m} \mathrm{hos} / \mathrm{cm}^{-1}$. The COD and BOD were within the high range of 4875 and $4168 \mathrm{mg} / \mathrm{l}$, respectively. The nitrates, organic nitrogen and chlorides were within the low range at the average of 15.8, 14.4 and 98 $\mathrm{mg} / \mathrm{l}$, successively. However, the phosphates and sulfates were slightly high at the range of 92.6 and $77 \mathrm{mg} / \mathrm{l}$, respectively. The average background concentration of copper, manganese and nickel was $0.09,0.71$ and $0.11 \mathrm{mg} / \mathrm{l}$, successively (Table 1).

TABLE 1. Physical and chemical characteristics and metals concentration of the selected food industrial wastewater (from period of 12 months).

\begin{tabular}{|c|c|c|c|}
\hline Parameters & Min. & Max. & Mean Value \\
\hline $\mathrm{pH}$ & 5.7 & 7.5 & 6.5 \\
\hline Temp. & 14.4 & 23.9 & 19.2 \\
\hline Turbidity (NTU) & 900 & 1100 & 1040 \\
\hline E.C. $\left(\mu \mathrm{mhos} / \mathrm{cm}^{-1}\right)$ & 600 & 1000 & 780 \\
\hline Total suspended solids (mg/l) & 246 & 664 & 485 \\
\hline $\mathrm{COD}\left(\mathrm{mgO}_{2} / 1\right)$ & 1267 & 6000 & 4875 \\
\hline $\mathrm{BOD}\left(\mathrm{mgO}_{2} / 1\right)$ & 1380 & 8360 & 4168 \\
\hline Nitrates mg/l & 9.1 & 29.0 & 15.8 \\
\hline Total Phosphates (mg PO4 ${ }^{3-} / 1$ ) & 50.5 & 173.5 & 92.6 \\
\hline Organic Nitrogen $\left(\mathrm{mg} \mathrm{N}_{2} / \mathrm{l}\right)$ & 10.2 & 20.1 & 14.4 \\
\hline Sulfates $(\mathrm{mg} / \mathrm{l})$ & 48 & 124 & 77 \\
\hline Chlorides $(\mathrm{mg} / \mathrm{l})$ & 42 & 121 & 98 \\
\hline Total solids (mg/l) & 908 & 2093 & 1632 \\
\hline Metals & & & \\
\hline Copper (mg/l) & 0.06 & 0.14 & 0.09 \\
\hline Manganese (mg/l) & 0.65 & 0.89 & 0.71 \\
\hline Nickel (mg/l) & 0.10 & 0.16 & 0.11 \\
\hline
\end{tabular}

Sodium hydroxide $(\mathrm{NaOH})$ at different $\mathrm{pH}$

By using sodium hydroxide as precipitant, the results obtained (Fig. 1) showed that increasing the $\mathrm{pH}$ value increased metals precipitation. The optimum $\mathrm{pH}$ for $\mathrm{Cu}, \mathrm{Ni}$ and $\mathrm{Mn}$ was 9.5 at which removal reached $97.5 \% 96.0 \%$, and $90.0 \%$, respectively. Increasing the $\mathrm{pH}$ value to 12 increased the removal of $\mathrm{Mn}$ to $93 \%$. Figure 1 represents the decrease of metal concentration at $\mathrm{pH} 9.5$ from $10.0 \mathrm{mg} / \mathrm{l}$ down to $0.25,0.40$ and $1.0 \mathrm{mg} / \mathrm{l}$ for $\mathrm{Cu}, \mathrm{Ni}$ and $\mathrm{Mn}$, respectively. At $\mathrm{pH} 12.0$, removal of all the studied metals reached $100 \%$ residual concentration of $\mathrm{Cu}, \mathrm{Ni}$ and $\mathrm{Mn}$ was further decreased down to zero $\mathrm{mg} / \mathrm{l}$.

Ferric chloride $\left(\mathrm{FeCl}_{3}\right)$ in combination with sodium hydroxide at different $\mathrm{pH}$

The use of ferric chloride $\left(\mathrm{FeCl}_{3}\right)$ at different $\mathrm{pH}$ values was also investigated. Sodium hydroxide was used to cover the $\mathrm{pH}$ range between 2.0 and 12.0 along with the addition of $50 \mathrm{mg} / \mathrm{l}$ ferric chloride; that is equivalent to 17.22 $\mathrm{mg} \mathrm{Fe} / \mathrm{l} /$; at each point. The results (Fig. 2) indicate that the removal efficiency was improved noticeably. At $\mathrm{pH} 7.5$ the removal of $\mathrm{Cu}$ and $\mathrm{Ni}$ reached $95 \%$ each, while $\mathrm{Mn}$ was removed only at $81 \%$. The residual concentration of $\mathrm{Cu}$ and $\mathrm{Ni}$

Egypt. J. Chem. 58, No. 1 (2015) 
was $0.5 \mathrm{mg} / \mathrm{l}$ each and was $1.9 \mathrm{mg} / \mathrm{l}$ for $\mathrm{Mn}$. The optimum $\mathrm{pH}$ was 9.0. The removal rate of all the studied metals increased up to $95 \%$ at which the residual concentration of each metal was $0.5 \mathrm{mg} / \mathrm{l}$. Further increase of $\mathrm{pH}$ to 12 increases the removal of all metals up to $98 \%$ at which the residual concentration of each metal was further decreased down to $0.2 \mathrm{mg} / \mathrm{l}$ (Fig. 2). Iron will be precipitated with the other metals, because $\mathrm{FeCL}_{3}$ here is a co- precipitant. Sodium hydroxide is the main agent that forms the hydroxides of metals here.

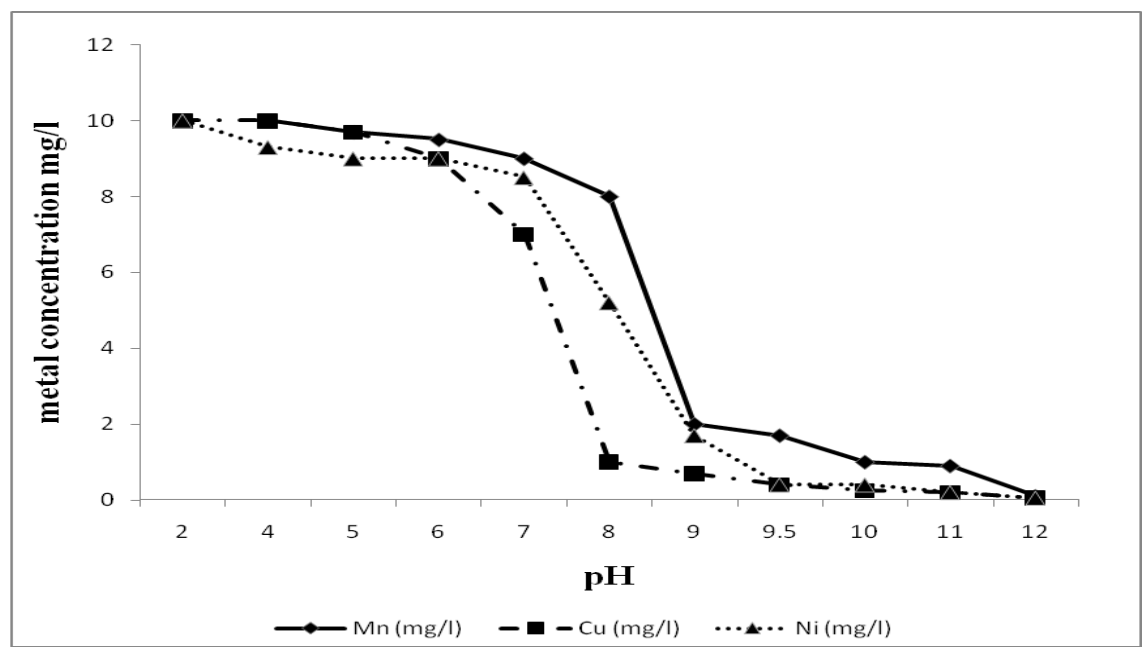

Fig.1. Effect of $\mathrm{NaOH}$ at different $\mathrm{pH}$ values on the precipitation of $\mathrm{Mn}, \mathrm{Cu}$ and $\mathrm{Ni}$ in artificial contaminated industrial wastewater.

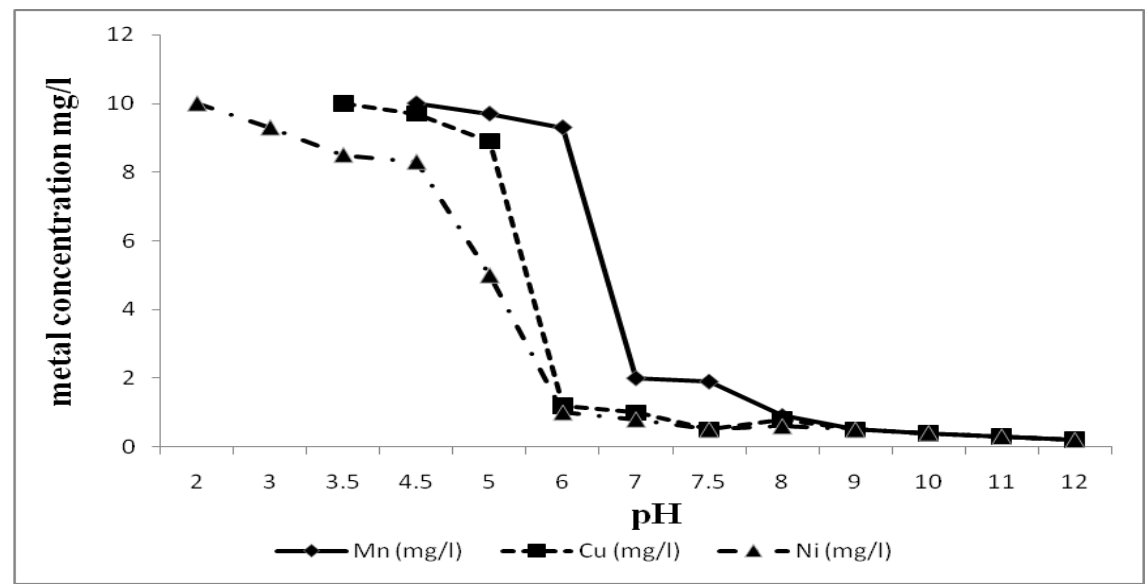

Fig. 2. Effect of $\mathrm{NaOH}$ combined with $\mathrm{FeCl}_{3}$ at different $\mathrm{pH}$ values on the precipitation of $\mathrm{Mn}, \mathrm{Cu}$ and $\mathrm{Ni}$ in artificial contaminated industrial wastewater. 
Alum in combination with sodium hydroxide at different $\mathrm{pH}$

The use of alum as $\left[\mathrm{Al}_{2}\left(\mathrm{SO}_{4}\right)_{3} .18 \mathrm{H}_{2} \mathrm{O}\right]$ at different $\mathrm{pH}$ values ranging from 2.0 to 12.0 was also carried out. Sodium hydroxide was further used to adjust the $\mathrm{pH}$ values at a constant alum dosage of $70 \mathrm{mg} / \mathrm{l}$, which is equivalent to $2.17 \mathrm{mg}$ $\mathrm{Al}^{+3} / \mathrm{l}$. The results (Fig. 3) indicate that optimum pH value was 9.5 at which $98 \%$ of $\mathrm{Cu}, 96 \%$ of $\mathrm{Ni}$ and $84 \%$ of $\mathrm{Mn}$ were removed. Residual concentration of metals was decreased down to $0.2,0.4$ and $1.6 \mathrm{mg} / \mathrm{l}$ for $\mathrm{Cu}, \mathrm{Ni}$ and $\mathrm{Mn}$, respectively. Increasing the $\mathrm{pH}$ up to 12.0 the removal rate of $\mathrm{Cu}$ and $\mathrm{Ni}$ reached $100 \%$ (i.e. residual concentration zero $\mathrm{mg} / \mathrm{l}$ ). However, the removal rate of $\mathrm{Mn}$ did not exhibit any further increase and was still at $84 \%$. Aluminum will be precipitated with the other metals, because alum here is a co- precipitant. Sodium hydroxide is the main agent that forms the hydroxides of metals here.

\section{The use of lime at different doses}

Further study was carried out to investigate the use of lime $(\mathrm{CaO})$. Different doses of lime were added to wastewater ranging from 50 to $300 \mathrm{mg} / \mathrm{l}$. The study covered the range of $\mathrm{pH}$ from 2.0 up to 12.0 according to the addition of lime dose to the wastewater. Remarkable improvement in the precipitation system was demonstrated by increasing the $\mathrm{pH}$ value (Fig. 4). At $220 \mathrm{mg} / \mathrm{l}$ lime the $\mathrm{pH}$ reached 9.0 at which over $98 \%$ of $\mathrm{Cu}$ and $\mathrm{Ni}$ each was removed. The residual concentration decreased to $0.2 \mathrm{mg} / \mathrm{l} \mathrm{each}$. At this point, $\mathrm{Mn}$ removal reached $93 \%$ and the residual concentration was $0.7 \mathrm{mg} / \mathrm{l}$. By increasing the $\mathrm{pH}$ to 10.0 , the optimum removal of $\mathrm{Mn}$ was achieved namely $96 \%$ with a residual concentration at $0.4 \mathrm{mg} / \mathrm{l}$. Increasing the $\mathrm{pH}$ to 11.0 increased the removal of $\mathrm{Cu}$ and $\mathrm{Ni}$ up to $100 \%$, while the removal rate of $\mathrm{Mn}$ did not show any further improvement (Fig. 4).

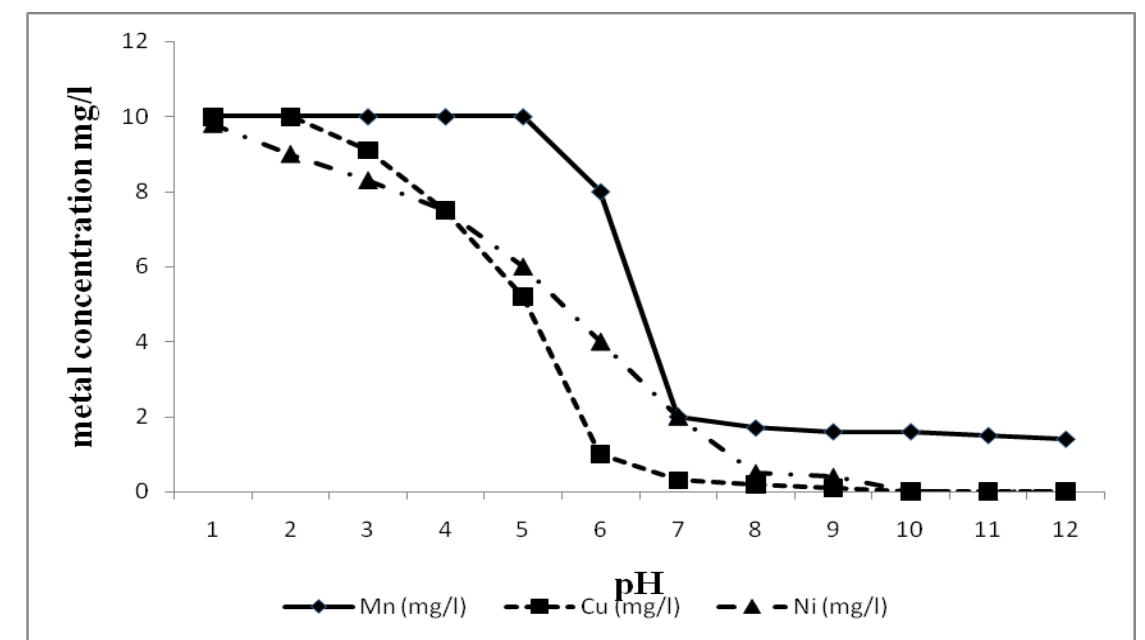

Fig. 3. Effect of $\mathrm{NaOH}$ combined with Alum at different $\mathrm{pH}$ values on the precipitation of $\mathrm{Mn}, \mathrm{Cu}$ and $\mathrm{Ni}$ in artificial contaminated wastewater.

Egypt. J. Chem. 58, No. 1 (2015) 


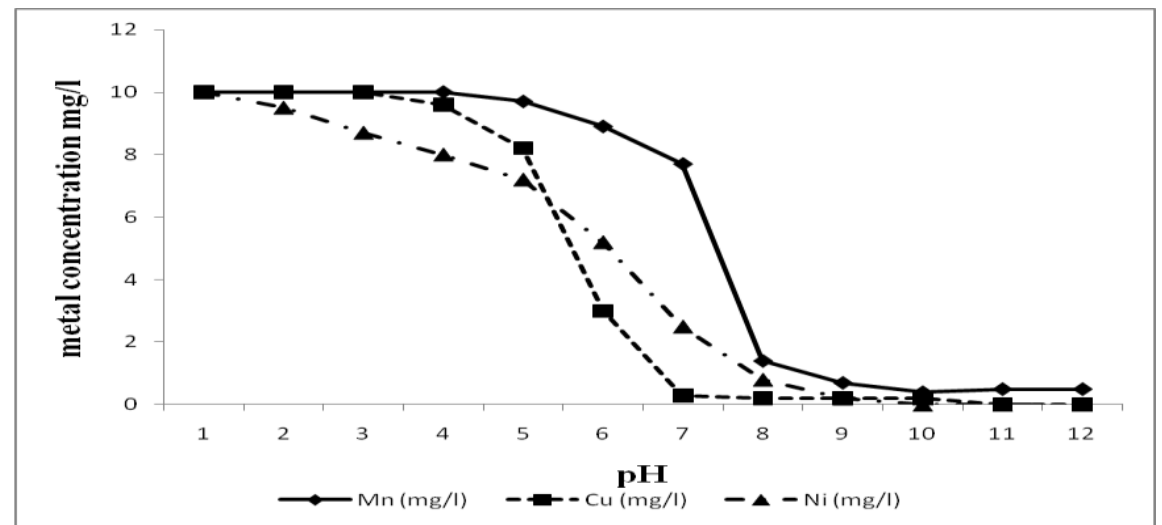

Fig. 4. Effect of different lime (CaO) doses on the removal $\mathrm{Mn}, \mathrm{Cu}$ and $\mathrm{Ni}$ in artificial contaminated wastewater.

The use of limestone at different doses

Use of limestone $\left(\mathrm{CaCO}_{3}\right)$ at different doses covering the range from $0.2 \mathrm{~g} / 1$ to $5.0 \mathrm{~g} / \mathrm{l}$ was investigated. Results obtained (Fig. 5) showed that increasing the $\mathrm{CaCO}_{3}$ dose from 100 to $2000 \mathrm{mg} / \mathrm{l}$ led to a slow increase in the $\mathrm{pH}$ value up to 6.5 (Table 2). Further addition of $\mathrm{CaCO}_{3}$ up to $4.0 \mathrm{~g} / 1$ exhibited very slow increase of the $\mathrm{pH}$ up to 7.5 which is attributed to carbonate buffering capacity system. The removal rate of the metals studied (Fig. 5) showed that use of $1.0 \mathrm{~g} / 1$ raised the $\mathrm{pH}$ to 5.85 and the removal of $\mathrm{Cu}, \mathrm{Ni}$ and $\mathrm{Mn}$ to $100,90.2$ and $75.1 \%$, respectively. By increasing the $\mathrm{CaCO}_{3}$ to $3.0 \mathrm{~g} / \mathrm{l}$, the $\mathrm{pH}$ reached 7.0 at which $100 \%$ of $\mathrm{Cu}$ and $\mathrm{Ni}$ each was achieved. At this point $\mathrm{Mn}$ removal reached $90.6 \%$ (i.e. residual concentration was $0.94 \mathrm{mg} / \mathrm{l}$, Fig. 5). One significant benefit of the $\mathrm{CaCO}_{3}$ is the buffering effect provided by both carbonate and bicarbonate ions. Table 2 records the gradual change in the $\mathrm{pH}$ of the wastewater according to the added dose of limestone.

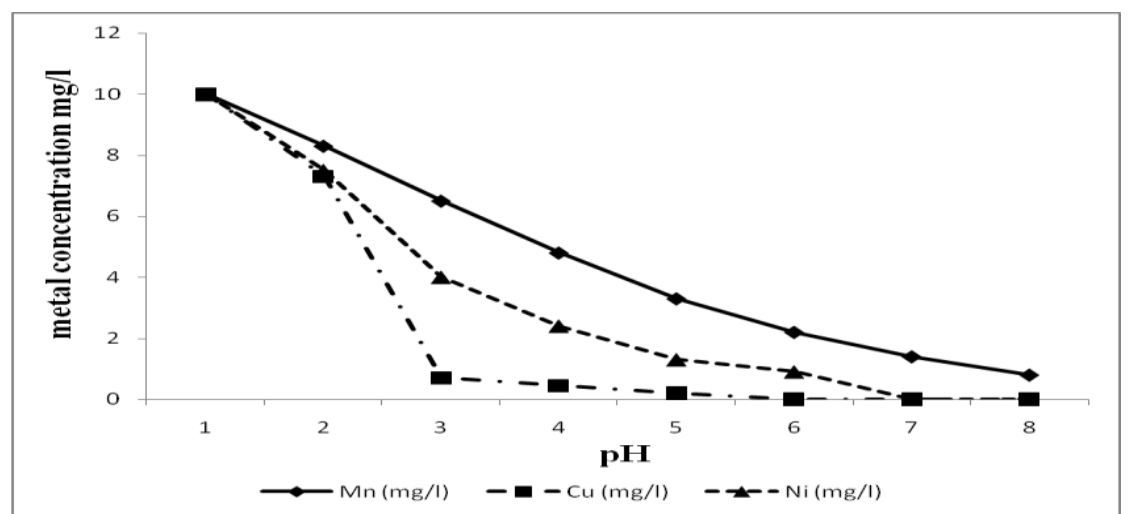

Fig. 5. Effect of different doses of lime (CaO) on the precipitation of $\mathrm{Mn}, \mathrm{Cu}$ and $\mathrm{Ni}$ in artificial contaminated water. 
TABLE 2. Effect of different calcium carbonate $\left(\mathrm{CaCO}_{3}\right)$ doses on the $\mathrm{pH}$ of the artificial contaminated industrial wastewater.

\begin{tabular}{|c|c|}
\hline Limestone $\left(\mathrm{CaCO}_{\mathbf{3}}\right)$ dose $(\mathbf{m g} / \mathbf{l})$ & $\begin{array}{c}\text { pH value of the } \\
\text { wastewater }\end{array}$ \\
\hline 0.0 & 2.0 \\
\hline 100 & 3.0 \\
\hline 250 & 4.3 \\
\hline 500 & 5.0 \\
\hline 1000 & 5.85 \\
\hline 2000 & 6.5 \\
\hline 3000 & 7.0 \\
\hline 4000 & 7.5 \\
\hline 5000 & 8.0 \\
\hline
\end{tabular}

Correlation between the efficiency of the studied chemical coagulants on the removal of $\mathrm{Cu}, \mathrm{Ni}$ and $\mathrm{Mn}$ at the optimum $\mathrm{pH}$ is given in Table 3. This correlation shows that the examined chemical coagulants were all efficient in the removal of the studied metals. Between 95 to $100 \%$ of $\mathrm{Cu}$ and $\mathrm{Ni}$ could be removed. However, Mn was less removed within the range between 90 to $99 \%$. The highest efficiency of chemical coagulants was exhibited by lime and limestone. Nevertheless, the later required high dose between 3000 or $5000 \mathrm{mg} / \mathrm{l}$ to reach pH 7.0 and 8.0, respectively. On the other hand, lime exhibited high efficiency of metals removal at $\mathrm{pH} 10.0$ (Table 3). Still, lime removal efficiency at $\mathrm{pH} 9.0$ was $98.0 \%$ for $\mathrm{Cu}$ and $\mathrm{Ni}$ each and $93.0 \%$ for $\mathrm{Mn}$.

TABLE 3. Correlation between the efficiency of the studied chemical coagulants on the removal of $\mathrm{Cu}, \mathrm{Ni}$ and $\mathrm{Mn}$ at the optimum $\mathrm{pH}$.

\begin{tabular}{|l|c|c|c|c|}
\hline \multirow{2}{*}{$\begin{array}{l}\text { Chemical } \\
\text { coagulant }\end{array}$} & \multirow{2}{*}{$\begin{array}{c}\text { Optimum } \\
\mathbf{p H}\end{array}$} & \multicolumn{3}{|c|}{ \% of metal removal } \\
\cline { 3 - 5 } & 9.5 & 97.5 & 96.0 & $\mathbf{~} \mathbf{\text { Nn }}$ \\
\hline $\mathrm{NaOH}$ & 9.0 & 95.0 & 95.0 & 90.0 \\
\hline $\mathrm{FeCl}_{3}+\mathrm{NaOH}$ & 9.5 & 98.0 & 96.0 & 85.0 \\
\hline Alum $+\mathrm{NaOH}$ & 9.0 & 98.0 & 98.0 & 93.0 \\
\hline \multirow{2}{*}{$\mathrm{Lime}(\mathrm{CaO})$} & 10.0 & 98.0 & 99.0 & 99.0 \\
\cline { 2 - 5 } & 8.0 & 100 & 100 & 96.0 \\
\hline $\begin{array}{l}\text { Limestone } \\
\left(\mathrm{CaCO}_{3}\right)\end{array}$ & 7.0 & 100 & 100 & 90.6 \\
\cline { 2 - 5 }
\end{tabular}

It can be concluded that the co-precipitation of metal hydroxides is governed by the concentration of metal ion in solution and the $\mathrm{pH}$ value. As the $\mathrm{pH}$ increases, the co-precipitation of metal hydroxide increases. However, certain amphoteric metals will re-dissolved at high $\mathrm{pH}^{(16,21)}$. This relationship is mostly governed by the following solubility product equation: ${ }^{(21)}$

$$
\left(\mathrm{M}^{+2}\right)(\mathrm{OH})^{2}=====\mathrm{K} \mathrm{sp} \text { (solubility constant). }
$$

Egypt. J. Chem. 58, No. 1 (2015) 
The solubility product constants for a number of metals have been already published $^{(21)}$. However, because of precipitates aging, incomplete solid separation, or co-precipitation and adsorption effects in wastewater, solubility products provide only general guide to residual metals concentration to be expected in practice ${ }^{(22,23)}$.

The overall results indicate that the optimum $\mathrm{pH}$ for hydroxide precipitation of the studied metals is varied between $\mathrm{pH} 6.5$ and 11.0. Since all effluent guidelines require an effluent $\mathrm{pH}$ between 6 and 9 , the use of carbonate treatment is, therefore, recommended because its buffering capacity value is around $\mathrm{pH} 7$. However, lime $(\mathrm{CaO})$ provides substantial precipitation capacity and an economic mean of treatment for heavy metal removal. The disadvantage is the difficulty to control the $\mathrm{pH}$ of the liquid waste. To get over such disadvantage acids and $\mathrm{NaOH}$ could be used to control the required $\mathrm{pH}$ if needed. The sludge formed could be handled as hazard chemicals since it contains heavy metals. However, the most important is that heavy metals were removed from the wastewater that could be reused safely without any hazard to man.

\section{Conclusion}

Removal of metals from liquid waste can be achieved efficiently by increasing the $\mathrm{pH}$ value of treatment system. Chemical coagulation including lime $(\mathrm{CaO})$, limestone $\left(\mathrm{CaCO}_{3}\right)$ and perhaps sodium hydroxide is effective in the precipitation and / or decreasing the solubility of heavy metals in the industrial wastewater.

A major environmental variable that determines the mobility of most metals in water is $\mathrm{pH}$. As $\mathrm{pH}$ drops below approximately $\mathrm{pH} 10$ or 11, most metals increase their solubility in water exponentially with the exception of carbonate precipitation. At high $\mathrm{pH}$ and low solubility, metals may either precipitate out of solution or bind to solid particles in the adsorption process.

Acknowledgement: The author wishes to express his deep appreciation and gratitude to the fund provided by the project titled "Sustainable Development for Wastewater Treatment and Reuse via Constructed Wetlands in Sinai (SWWTR)" that funded STDF of Egypt.

\section{References}

1. Moore, J. W. and Romanorty, S., Heavy Metals in Natural Waters, Applied Monitoring and Impact Assessment. Springer-Verlag, Berlin. p. 222(1984).

2. Patterson, J.W., "Water Treatment Technology" , Arbor Science Publishing Inc., Ann Arbor, Michigan, 183 pp. (1975). 
3. Abdel-Sabour, M.F., Abdel-Shafy, H.I. and Mosalem, T.M., Heavy metals and plant growth yield as effected by sewage sludge and water hyacinth compost applied to sandy soil. J. Environmental Protection Engineering, 27(2), 43-53 (2001).

4. Foerstner, U. and Wittmann, G.I., Metals Pollution in the Aquatic Environment. Springer-Verlag, Berlin-Heidelberg, N.Y. page 485 (1983).

5. Scammell, M. S., Batley, G.E. and Brockbank, C.I., A field study of the impact on oysters of tributyltin introduction and removal in a pristine lake. Archives of Environmental Contamination and Toxicology. pp. 276-281(1991).

6. Okia, O.T., Characterisation of wastewater purification by cyperus papyrus floating in segmented channel. M.Sc. Thesis EE 107 IHE, Delft (1993).

7. Abdel-Shafy, H.I. and Aly, R.O., Wastewater Management in Egypt. In: Wastewater Reuse-Risk Assessment, Decision-Making and Environmental Security. Mohammed K. Zaidi (Ed.) Springer Publisher, Netherland, 375-382 (2007).

8. Tchnobanoglous, G., Constructed wetlands for waste water treatment engineering considerations. In: P. F. Copper and B. C. Findlate (Ed.). Constructed Wetlands in Water Pollution Control. Advances in Water Pollution Control. Pergamon Press, Oxford 11, 431- 494(1990).

9. Abdel-Shafy, H.I., Al-Sulaiman, A.M. and Mansour, Mona S.M., Greywater treatment via hybrid integrated systems for unrestricted reuse in Egypt. J. Water Process Eng. 1,101-107 (2014), http://dx.doi.org/10.1016/j.jwpe.2014.04.001.

10. Stronach, S.M., Ruddd, T. and Lester J.N., Anaerobic Digestion Process in Industial Wastewater Treatment. Springer-Verlag, Berlin (1986).

11. Abdel-Shafy, H.I. and Salem M.A.M., Efficiency of oxidation ponds for wastewater treatment in Egypt In: Wastewater Reuse-Risk Assessment, Dicision-Making and Environmental Security. Mohammed K. Zaidi (Ed.) Springer Publisher, Netherland, pp.175-184 (2007).

12. Abdel-Shafy, H.I. and El-Khateeb M.A., Integration of septic tank and constructed wetland for the treatment of wastewater in Egypt. J. Desalination and Water Treatment, Taylor \& Francis Publisher, April, 51, 3539-3546 (2013).

13. Abdel-Shafy, H.I. and Aly, R.O., Water issue in Egypt: resources, pollution and protection endeavors. Central European J. Occupational \& Environ. Medicine, 8 (1), $1-21(2002)$.

14. Brown, P.A., Gill, S.A. and Allen, S.J., Metal removal from wastewater using peat. Water, 34(16), 3907-3916 (2000).

15. Abdel-Shafy, H.I., Hegemann, W., Schenck, H. and Wilke, A., Decreasing the level of heavy metals by the aerobic treatment of tannery wastewater. Central European J. of Occupational \& Environ. Medicine, 8 (4), 298-309 (2002). 
16. El-Gohary, F.A., Lasheen, M.R. and Abdel-Shafy, H.I., Heavy Metals-Environ. Intern 'l Conf., Amsterdam, pp. 26-29, Sept, (1981).

17. Alloway, B.J. and Ayre, D.C., Chemical Principles of Environmental Pollution. Blackie Academic and Professional, London (1993).

18. Abdel-Shafy, H.I., Inka Hobus and Werner Hegemann, Upgrading of decentralized ponds for municipal wastewater treatment and restricted Reuse. J. Water reuse and Desalination, 01(3), 141-151 (2011).

19. Culp, G.L. and Culp, R.I., New concepts-wat. purif., Von Nostrand Reinhold Environmental Eng. Series, Ny, 247 pp. (1974).

20. APHA, AWWA and WEF, Standard Methods for the Examination of Water and Wastewater, $21^{\text {st }}$ ed., American Public Health Association, Washington, DC (2005).

21. Feitknecht, W. and Schindler, P., Pure Appl. Chem. 6,130 (1963).

22. Abdel-Shafy, H.I., Hegmann, W. and Gueldner, C., Fate of heavy metals via chemical-biological upgrading of sewage treatment plant. J. Environmental Management \& Health, 7(3), 28-3 (1996).

23. Tcgobanoglous, G. and Burton, F.L., Wastewater Engineering; Treatment, Disposal and Reuse. McGraw-Hill. New York (1991).

(Received 24/6/2013;

accepted 17/2/2015) 


\section{ازالة المعادن الثقيلة من المخلفات الصناعية السائلة باستخدام المجلطات الكيميائية

$$
\text { حسين إبراهيم عبد الثافى تئى }
$$$$
\text { قسم بحوث تلوث المياه ـ المركز القومى للبحوث ـ الدقى ـ القاهرة - مصر. }
$$

تتناول هذه الدراسة ترسيب المعادن من المخلفات السائلة باستخدام المجلطات

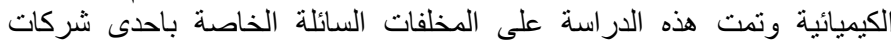

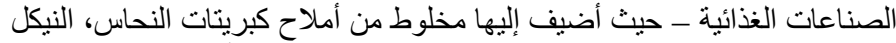

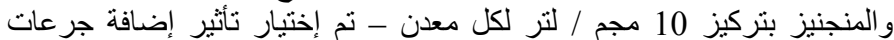

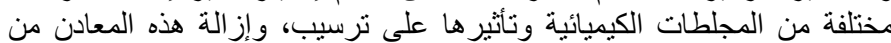

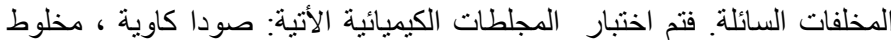

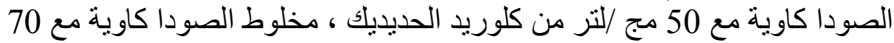
مج /لتر من الثبة ، الجير ، الحجر التر من الجيرى . الحرئ.

دلت النتائج عن فاعلية المعالجة الكيميائية لترسيب المعادن المختبرة بنسب

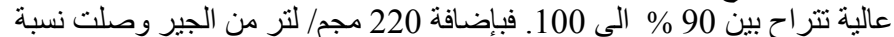

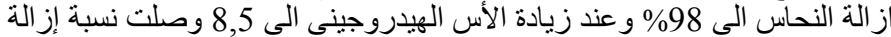

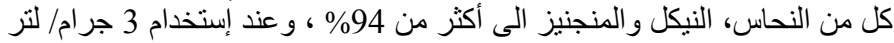

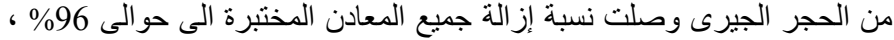

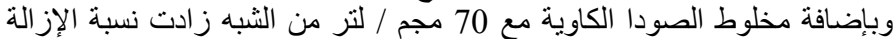

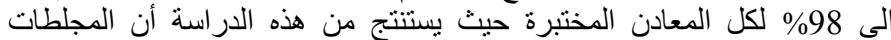

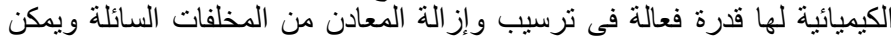

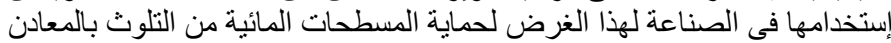
الناتجة من قذف هذه المخلفات السائلة. 